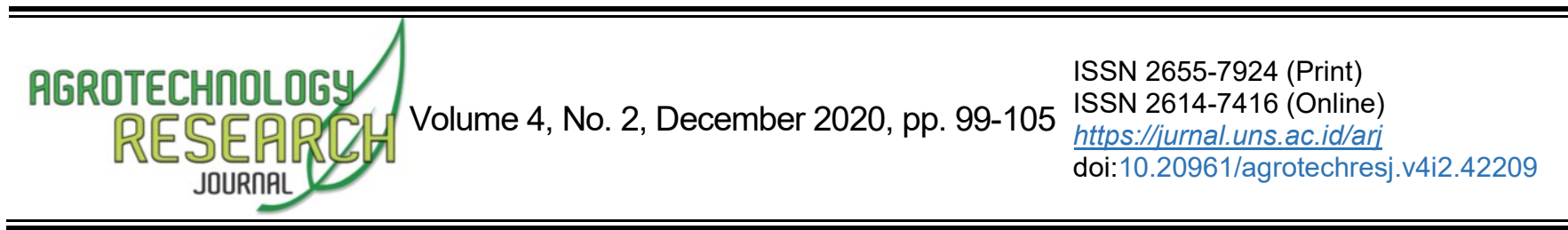

\title{
Physiological and Yield of Soybean Under Kayu Putih (Melaleuca cajuputi subsp. cumingiana) Stands with N, P, and K Fertilization on Lithic Haplustert
}

\author{
Roni Ismoyojati ${ }^{1 *}$, Tohari², Priyono Suryanto ${ }^{3}$, Fajrin Pramana Putra ${ }^{4}$ \\ ${ }^{1,4}$ Department of Plantation Production Technology, Politeknik Lamandau, Lamandau, Indonesia \\ ${ }^{2}$ Department of Agronomy, Faculty of Agriculture, Universitas Gadjah Mada, Yogyakarta, Indonesia \\ ${ }^{3}$ Department of Silviculture, Faculty of Forestry, Universitas Gadjah Mada, Yogyakarta, Indonesia
}

Received 21 June 2020; Accepted 06 November 2020; Published 1 December 2020

\begin{abstract}
Fertilization of N, P, and K on soybean planted under Kayu Putih stands to serve to increase soil nutrients. Lithic Haplustert is a subgroup of Vertisol with a relatively low fertility and organic matter with a heavy clay texture. This research aims to determine the response of soybean to the application of $\mathrm{N}$, $\mathrm{P}$, and $\mathrm{K}$ fertilizers on the Lithic Haplustert in physiology and yield. This research was conducted from February to May 2015 in the Srikoyo hamlet, Menggoran village, Playen district, Gunungkidul regency, Yogyakarta. The experimental design is split-split plot with three levels of fertilization of $\mathrm{N}\left(0,25,50 \mathrm{~kg}\right.$ urea ha-1), $\mathrm{P}\left(0,150,300 \mathrm{~kg} \mathrm{SP}-36 \mathrm{ha}^{-1}\right)$, and $\mathrm{K}(0,75,150 \mathrm{~kg} \mathrm{KCl} \mathrm{ha-1})$. The results showed that the application of $50 \mathrm{~kg}$ urea ha-1 and $300 \mathrm{~kg} \mathrm{SP}-36 \mathrm{ha}^{-1}$ can increase the leaf area and photosynthesis rate. Dosage $150 \mathrm{~kg} \mathrm{KCl} \mathrm{ha}^{-1}$ fertilizer increased the concentration of $\mathrm{N}, \mathrm{P}$, and $\mathrm{K}$ in the plant tissues significantly.
\end{abstract}

Keywords: Soybean; Fertilizer; Photosynthetic rate; Vertisol

Cite This As (CSE Style): Ismoyojati R, Tohari, Suryanto P, Putra FP. 2020. Physiological and Yield of Soybean (Glycine max (L.) Merrill) Under Kayu Putih (Melaleuca cajuputi subsp. cumingiana) Stands with N, P, and K Fertilization on Lithic Haplustert. Agrotech Res J. 4(2): 99-105. https://doi.org/10.20961/agrotechresj.v4i2.42209

\section{INTRODUCTION}

Soybean (Glycine max (L.) Merrill) is one of the most important crops worldwide. It is a particularly important source of protein $(35-40 \%)$ and vegetable oil for most people in the world (Day 2013; Janagard et al. 2013). The increase in the world population will increase food needs. World soybean production increased by $4.6 \%$ from the year 1961 to 2007 and is expected to continue to increase every year (Masuda and Goldsmith 2009). The increase of soybean production can only partly be attained using the available land under forestry bringing to agriculture (Gibbs et al. 2010; Tscharntke et al. 2012).

The soil is the medium for plants to grow. In addition, the soil has a role in providing nutrients for plants. Many kinds of soil fertility vary depending on the environment and the soil-forming material. Soil classification has been done to make it easier to understand the types of soil in the world, one of which soil classification systems conducted by the United States Department of Agriculture (USDA). Lithic Haplustert is a subgroup of Vertisols that have Lithic contact within $50 \mathrm{~cm}$ of the mineral soil surface. Boundaries Lithic contact between

${ }^{*}$ Corresponding Author:

E-Mail: ismoyojatironi@gmail.com the ground and underlying material is coherent, while Ustert (soil moisture regime Ustic) is Vertisol which, if not irrigated throughout the year, had a crack width of $5 \mathrm{~mm}$ or more, reaching a thickness of $25 \mathrm{~cm}$ or more within 50 $\mathrm{cm}$ of the mineral soil surface, for a cumulative 90 days or more each year in normal years (Soil Survey Staff 2014). This causes the Vertisol to have low fertility rates such as nitrogen, phosphorus, potassium, and organic matter content to affect the growth of soybean (Novelli et al. 2011).

The response of soybean plants to deficient nitrogen $(\mathrm{N})$ would affect the photosynthetic process and growth. The growth parameters such as LAl, plant biomass, and leaf photosynthesis reduced due to limited nitrogen availability (Valentine et al. 2018). Phosphorus is the second important element that limits plant growth in the case of unavailability. The most important phosphorus sources in arable soils are chemical fertilizers, but 75 to 90 percent of the phosphorus combines with $\mathrm{Fe}, \mathrm{Ca}$, and Al in soil (Ao et al. 2014). Phosphorus (P) deficiency will affect soybeans leaf initiation stage (Singh and Reddy 2016).

The main role of potassium is to activate many enzymes in plants, and such enzymes act as a catalyst for making materials such as starch and protein. Potassium also plays a role in photosynthesis, osmotic adjustment, cell growth, stomatal regulation, water 
system of the plant, downloading hydrocarbons made in the leaves into the phloem, transporting them within the plant, anion cation balance, and as accompanying cation in nitrogen transfer (Motaghi and Nejad 2014). Potassium (K) deficiency will affect the yield and quality of seed production (Putra, Saparso, Rohadi, et al. 2019). Fertilization management is needed to provide the availability of nutrients in the Vertisol, especially nitrogen $(\mathrm{N})$, phosphorus $(\mathrm{P})$, and potassium (K) (Putra, Saparso, Suparto, et al. 2019). This study aimed to determine the physiological responses that affect the soybean yields with the application of N, P and K fertilizers in the Lithic Haplustert.

\section{MATERIALS AND METHODS \\ Site description}

The research was conducted from February to May 2015 in the Srikoyo Hamlet, Menggoran Village, Playen District, Gunungkidul Regency, Yogyakarta (070 55' $\left.17,3^{\prime \prime} \mathrm{S}, 110^{\circ} 34^{\prime} 35,7^{\prime \prime} \mathrm{E}\right)$. The average of rainfall, air temperature, and air relative humidity from February to May 2015 is $215 \mathrm{~mm} / \mathrm{month}, 26^{\circ} \mathrm{C}$, and $86 \%$, respectively. The soil profile was prepared and used to classify the soil based on the soil morphology; the result is presented in Table 1.

Table 1. Soil condition in Srikoyo Hamlet, Menggoran Village, Playen District, Gunungkidul Regency, Yogyakarta

\begin{tabular}{ll}
\hline & Soil Classification \\
\hline Landform & Flat/Inter-mountain valley \\
Elevation & 177 m above sea level \\
Parent material & Limestone \\
& Cultivation of Kayu Putih \\
Land use & forests and seasonal \\
& crops \\
Ordo & Vertisol \\
Sub-ordo & Ustert \\
Great group & Haplustert \\
Sub-group & Lithic Haplustert \\
\hline
\end{tabular}

\section{Soil fertility and experimental treatment}

Observations of soil fertility based on soil chemical and physical properties are obtained by taking soil samples at a depth of $0-20 \mathrm{~cm}$ and $20-40 \mathrm{~cm}$. Soil samples as much as $5 \mathrm{~kg}$ were collected at a depth of 0 $20 \mathrm{~cm}$ and $20-40 \mathrm{~cm}$, respectively. The appropriate methods used for soil properties analysis are as follows: $\mathrm{pH} \mathrm{H}_{2} \mathrm{O}$ (2:1), C-Organic (Walkley-Black), N-total (Kjeldahl), P-available (Olsen), Exchangeable $\mathrm{K}^{+}$(Flame photometer), Exchangeable $\mathrm{Ca}^{2+}$ (EDTA), CEC, and base saturation (saturation with ammonium acetate $1 \mathrm{~N}$ $\mathrm{pH}$ 7.0). Results of chemical analysis of soil indicated that the $\mathrm{pH}$ value at a depth of $0-20 \mathrm{~cm}$ and $20-40 \mathrm{~cm}$ is 7.19 and 7.17 , respectively, at the rate of a neutral condition. The content of C-organic and $\mathrm{N}$-total at a depth of $0-20 \mathrm{~cm}(1.20 \%$ and $12.10 \%)$ and $20-40 \mathrm{~cm}$
(1.30\% and $12.11 \%)$, in a low condition. The content of $\mathrm{P}$-available and exchangeable $\mathrm{K}^{+}$at a depth of $0-20 \mathrm{~cm}$ (24.58 ppm and $0.45 \mathrm{cmol} \mathrm{kg}^{-1}$ ) and $20-40 \mathrm{~cm} \mathrm{(30.35}$ ppm and $\left.0.50 \mathrm{cmol} \mathrm{kg}^{-1}\right)$, these values are considered as the moderate condition. The exchangeable $\mathrm{Ca}^{2+}, \mathrm{CEC}$ and base saturation at a depth of $0-20 \mathrm{~cm}(45.56 \mathrm{cmol}$ $\mathrm{kg}^{-1}, 55.20 \mathrm{cmol} \mathrm{kg}^{-1}$ and $\left.86.67 \%\right)$ and $20-40 \mathrm{~cm} \mathrm{(45.25}$ $\mathrm{cmol} \mathrm{kg}^{-1}, 55.80 \mathrm{cmol} \mathrm{kg}^{-1}$ and $85.43 \%$ ), in a very high condition. Soil texture is considered heavy clay due to be dominated by clay at a depth of $0-20 \mathrm{~cm}(72.80 \%)$ and $20-40 \mathrm{~cm}(74.13 \%)$. The results of soil chemical and physical properties are presented in Table 2.

Table 2. The physico-chemical analysis of soil before application of fertilizer

\begin{tabular}{|c|c|c|c|}
\hline \multirow{2}{*}{ Soil Properties } & \multicolumn{2}{|c|}{ Depth } & \multirow{2}{*}{ Rating } \\
\hline & $0-20 \mathrm{~cm}$ & $20-40 \mathrm{~cm}$ & \\
\hline $\mathrm{pH} \mathrm{H} \mathrm{H}_{2} \mathrm{O}$ & 7.19 & 7.17 & Neutral \\
\hline C-Organic (\%) & 1.20 & 1.30 & Low \\
\hline $\mathrm{N}(\%)$ & 0.10 & 0.11 & Low \\
\hline P-available (ppm) & 24.58 & 30.35 & Moderate \\
\hline Exch. $\mathrm{K}^{+}\left(\mathrm{cmolkg}^{-1}\right)$ & 0.45 & 0.50 & Moderate \\
\hline Exch. $\mathrm{Ca}^{2+}\left(\mathrm{cmolkg}^{-1}\right)$ & 45.56 & 45.25 & Very High \\
\hline CEC $\left(\mathrm{cmolkg}^{-1}\right)$ & 55.20 & 55.80 & Very High \\
\hline Base saturation (\%) & 86.67 & 85.43 & Very High \\
\hline Texture & - & - & \multirow{4}{*}{ Heavy Clay } \\
\hline \multirow{2}{*}{$\begin{array}{ll}- & \text { Clay }(\%) \\
- & \text { Silt }(\%)\end{array}$} & 72.80 & 74.13 & \\
\hline & 11.95 & 12.00 & \\
\hline - $\quad$ Sand $(\%)$ & 15.25 & 13.87 & \\
\hline
\end{tabular}

The experimental treatments were arranged in a splitsplit plot design with Latin Square Design (LSD) as an environmental experiment. The main plot, subplots, and sub-sub plots are fertilization of urea (N), SP-36 (P), and $\mathrm{KCl}(\mathrm{K})$, respectively. Each one of fertilization consists of three levels $\left(0,25,50 \mathrm{~kg}_{\text {urea ha-1 }}\right),(0,150,300 \mathrm{~kg} \mathrm{SP}$ $\left.36 \mathrm{ha}^{-1}\right)$ and $\left(0,75,150 \mathrm{~kg} \mathrm{KCl} \mathrm{ha}^{-1}\right)$.

\section{Measurement of physiological variables}

The soybean variety used is Grobogan. The physiological parameters were observed until 63 days after sowing, while the yield components were determined at 72 days after sowing. The parameters of physiological processes and yield components were determined using the appropriate methods. Leaf area $\left(\mathrm{m}^{2}\right)$ was determined by using a leaf area meter, $\mathrm{N}, \mathrm{P}$, and $\mathrm{K}$ concentration of plant's tissue (\%) was determined by using samples of the leaf, photosynthetic rate $(\mu \mathrm{mol}$ $\mathrm{CO}_{2} \mathrm{~m}^{-2} \mathrm{~s}^{-1}$ ) was determined by using photosynthetic analyzer type LI-COR LI 640.

\section{Data analysis}

Data were analyzed using the analysis of variance (ANOVA) at $5 \%$ and $1 \%$ levels with SAS 1.9 software. The relationship between variables was obtained using regression analysis. A stepwise regression analysis was used to determine the physiological parameters that affect the yield and yield components (SAS Institute Inc. 2001). 


\section{RESULTS AND DISCUSSION}

Soybean treated with nitrogen $(\mathrm{N})$ and phosphorus (P) fertilizers on Lithic Haplustert showed a positive response in the expansion of leaves. Leaves are the primary photosynthetic organs of the plant in which the process of change of light energy into chemical energy and the production of carbohydrates in dry matter occurred. The combination rates of $50 \mathrm{~kg}^{\mathrm{m}}$ urea ha-1 and $300 \mathrm{~kg} \mathrm{SP}-36 \mathrm{ha}^{-1}$ produced a maximum leaf area of 0.25 $\mathrm{m}^{2}$ (Figure 1). The leaf area is strongly influenced by environmental factors, among which the light and the availability of $\mathrm{N}$ and $\mathrm{P}$ in the soil (Suryanto et al. 2017). Sunlight is optimally obtained by soybeans because there is no shade produced by Kayu Putih. The foliage pruning to harvest Kayu Putih causing no shade effects in the area of soybeans fields (Suryanto et al. 2017). The photosynthetic rate also increased at the application rates of $50 \mathrm{~kg}$ urea ha-1 and $300 \mathrm{~kg} \mathrm{SP}-36 \mathrm{ha}^{-1}$ is about $41.22 \mu \mathrm{mol} \mathrm{CO} 2 \mathrm{~m}^{-2} \mathrm{~s}^{-1}$ (Figure 1).

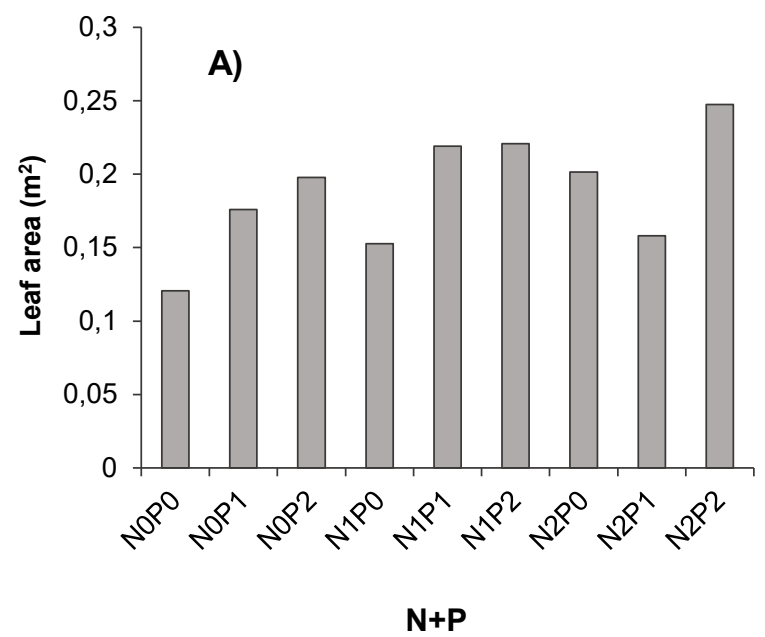

The relationship between leaf area and photosynthetic rate in various $\mathrm{N}$ and $\mathrm{P}$ rates shows a linear curve (Figure 2); thus, increasing the leaf area will be followed by an increase in the photosynthetic rate. Photosynthetic rate is one of the physiological variables related to crop production. During photosynthesis, the necessary light and nitrogen $(\mathrm{N})$ are an ingredient in the photosynthetic process. Chlorophylls, as the light receptor in photo-systems II and I, need the nitrogen (N) (Oliveira et al. 2013). The light reaction in the photosynthetic process will generate ATP and NADPHrequiring Phosphorus $(P)$ as an ingredient. Nitrogen $(N)$ and phosphorus $(P)$ are indispensable plants in the photosynthetic process as a constituent of chlorophyll and the establishment of energy used when carrying out the photosynthetic process, so that when the content of these two elements in plant's tissues increases, will optimize photosynthetic rate (Reich et al. 2009; Domingues et al. 2010).

Figure 1. A) Leaf area and B) Photosynthetic rate at various $N$ and $P$ fertilizer combinations: NOP0 $=0 \mathrm{~kg} \mathrm{urea} \mathrm{ha}^{-1}$ and $0 \mathrm{~kg} \mathrm{SP}^{-}$

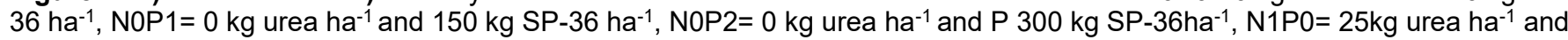

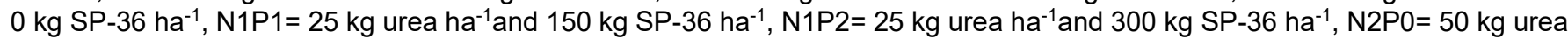
$\mathrm{ha}^{-1}$ and $0 \mathrm{~kg} \mathrm{SP}-36 \mathrm{ha}^{-1}, \mathrm{~N} 2 \mathrm{P} 1=50 \mathrm{~kg}$ urea ha-1 and P $150 \mathrm{~kg} \mathrm{SP}^{-36} \mathrm{ha}^{-1}, \mathrm{~N} 2 \mathrm{P} 2=50 \mathrm{~kg}$ urea ha-1 and $300 \mathrm{~kg} \mathrm{SP}-36 \mathrm{ha}^{-1}$

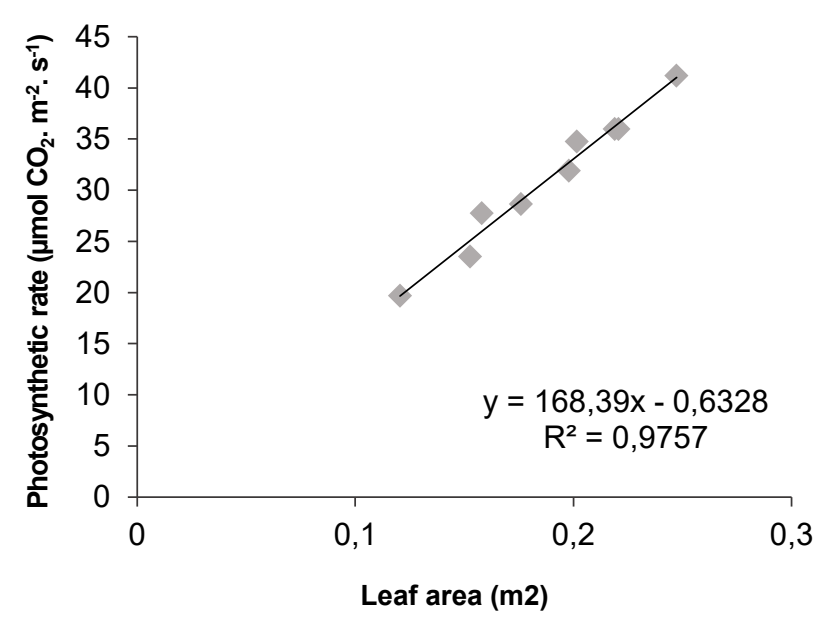

Figure 2. Relationship between Leaf Area and the Photosynthetic Rate in a Combination of $\mathrm{N}$ and $\mathrm{P}$ Fertilization Treatment

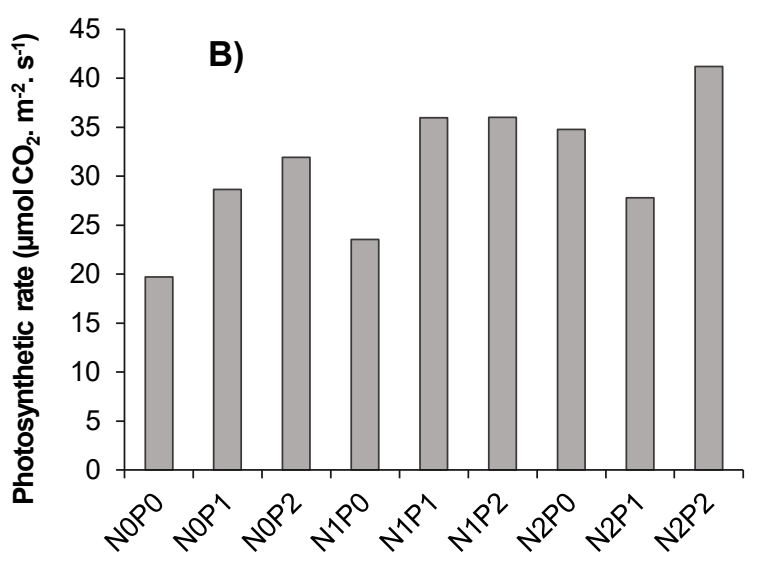

$N+P$

When $\mathrm{N}, \mathrm{P}$, and $\mathrm{K}$ fertilizer's application rate increased, the concentration of these three elements in the tissues also increased (Figure 3). Less than optimal availability of $\mathrm{N}, \mathrm{P}$, and $\mathrm{K}$ in the Lithic Haplustert given thought to cause fertilization could complete the lack of these elements in the soil solution. Proper management of Vertisol will result in maximum crop growth and yield (Cuvaca et al. 2015). On potato plants grown in Vertisol treated with $\mathrm{N}$ and $\mathrm{P}$ fertilizers, significantly increased the growth and yield (Zelalem et al. 2009; Putra, Saparso, Rohadi, et al. 2019). While the process of translocation in plants is inseparable from the role of potassium (K) because, in a case of $\mathrm{K}$ deficiency in the soil and the plant tissue, it will interfere with the absorption of other elements such as $\mathrm{N}, \mathrm{P}$ and assimilates translocation from source to sink (Kanai et al. 2011; Jati et al. 2017). 

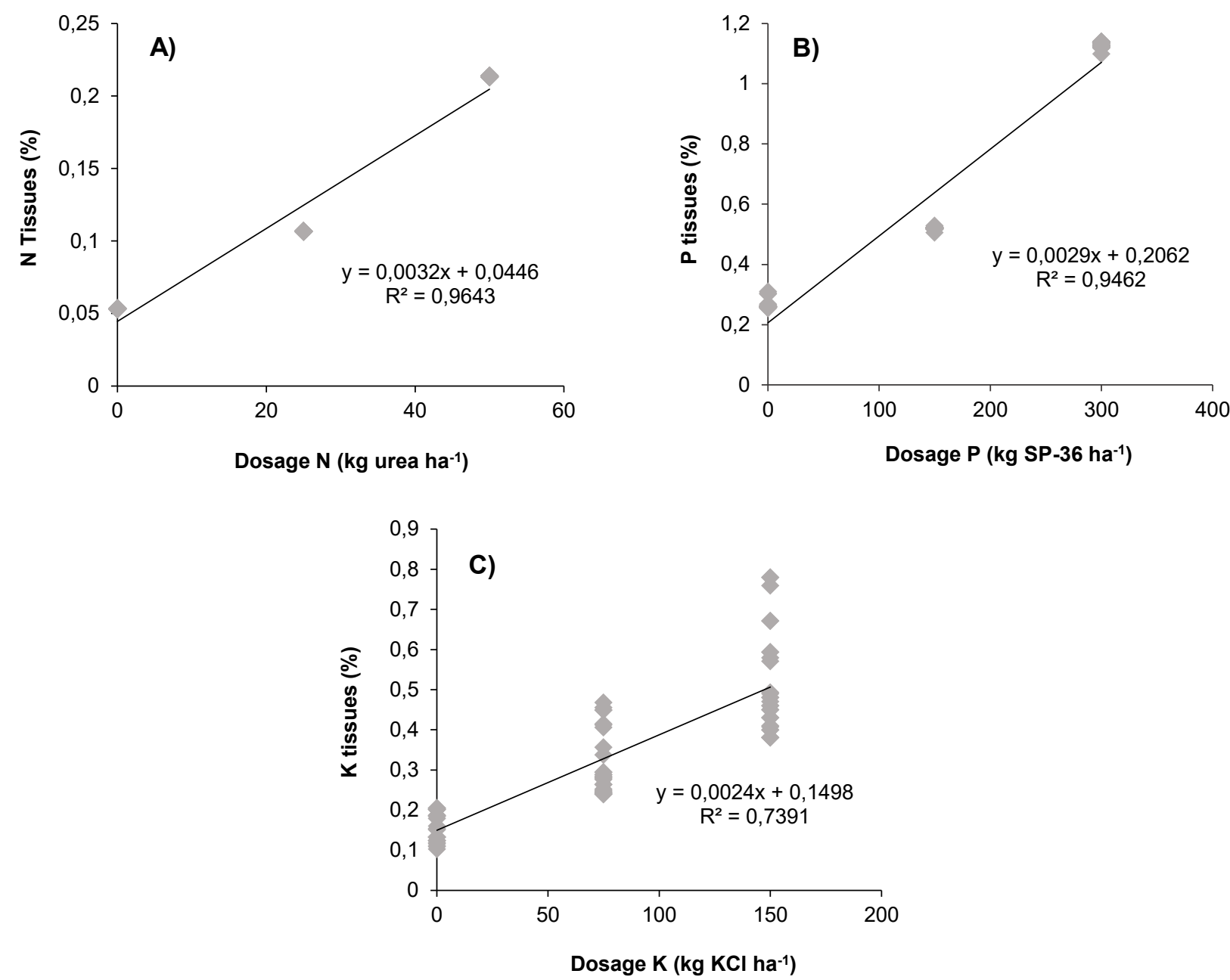

Figure 3. Relationship between the Application Rate of Fertilizer and the Concentration of $A)$ Nitrogen $(N)$, B) Phosphor(P) and C) Potassium (K) in the Plant Tissues, respectively

Physiological components affecting seed yield of soybean

The relationship is shown by physiological variables that affect the yield and yield components, i.e., the number of pods plant ${ }^{-1}$, the number of seed plant ${ }^{-1}$ and seed weight $\left(\right.$ g plant $\left.^{-1}\right)$ and seed yield $\left(\mathrm{t} \mathrm{ha}^{-1}\right)$ are affected by photosynthetic rate and $\mathrm{P}$ content in tissues (Table 3 ). Based on equations in Table 3 , as much as 22.79 pods plant $^{-1}, 42.56$ seeds plant ${ }^{-1}, 7.64 \mathrm{~g}$ seeds plant ${ }^{-1}$ and seed weight of $1.95 \mathrm{t} \mathrm{ha}^{-1}$, with a maximum photosynthetic rate of $41.22 \mu \mathrm{mol} \mathrm{CO} \mathrm{CO}^{2} \mathrm{~s}^{-1}$ (Figure 1) and the maximum of concentration of $P$ in plant's tissues of $1.08 \%$ (Figure 3 ) as independent variables.

One of the $\mathrm{P}$ roles in plant tissues for photosynthesis, is that the higher $P$ content in the plant tissues will increase photosynthetic rate. Increasing the amount of assimilates produced can be used to transition from the vegetative phase to the generative phase. The greater the organ of vegetative growth that serves as a producer of assimilates (source), the more the growth of the user organ (sink) will give optimum yields. Assimilates produced during the photosynthetic process then be translocated to all organs of the plant. If the soybean crop is still in the vegetative phase, then most assimilates formed in photosynthetic process will be translocated to the newly formed organs, and some will be stored as energy reserves (Putra et al. 2017). At the time soybean plants began to enter the generative phase, assimilates stored as energy reserves can be reused for the formation of seed and pods (Atkins and Smith 2007; Araújo et al. 2012).

Table 3. Stepwise regression analysis, relationship between physiological and yields components of soybean

\begin{tabular}{|c|c|c|}
\hline Dependent Variable & Independent Variable & $D^{2}$ \\
\hline Yield Component & Physiological Component & \\
\hline Number of pods plant ${ }^{-1}$ & $Y=16.20^{* *}+0.16^{* *}(\operatorname{Pr})$ & $0.15^{* *}$ \\
\hline Number of seeds plant ${ }^{-1}$ & $Y=31.02^{* *}+0.28^{* *}(\operatorname{Pr})$ & $0.12^{* *}$ \\
\hline Seed weight plant ${ }^{-1}$ & $Y=4.41^{* *}+0.05^{\star *}(\operatorname{Pr})+1.09^{*}(\mathrm{P})$ & $0.19^{* *}$ \\
\hline Seed yield & $Y=1.20^{* *}+0.01^{*}(\mathrm{Pr})+0.32^{*}(\mathrm{P})$ & $0.17^{* *}$ \\
\hline
\end{tabular}


Based on the results of the regression analysis Figure 4 , the relationship between the number of pods plant ${ }^{-1}$ and seeds plant ${ }^{-1}$ showed a linear curve. Increasing the number of pods plant ${ }^{-1}$ will be followed by an increase in the seeds plant ${ }^{-1}$.

Figure 5 and Figure 6 show a linear relationship between the number of seeds plant ${ }^{-1}$ with seed weight ( $\mathrm{g}$ plant $\left.{ }^{-1}\right)$ and seed weight $\left(g_{\text {plant }}^{-1}\right)$ with seed yield ( $t$ ha$\left.{ }^{1}\right)$. The Increasing number of seeds plant ${ }^{-1}$ will produce a high seed weight $\left(g\right.$ plant $\left.^{-1}\right)$. While the increase in seed weight $\left(\mathrm{g} \mathrm{plant}^{-1}\right)$ will produce high seed yield $\left(\mathrm{t} \mathrm{ha}^{-1}\right)$.

In soybean crops, pods and seeds are formed during the flowering period. Pods are one of the accumulations

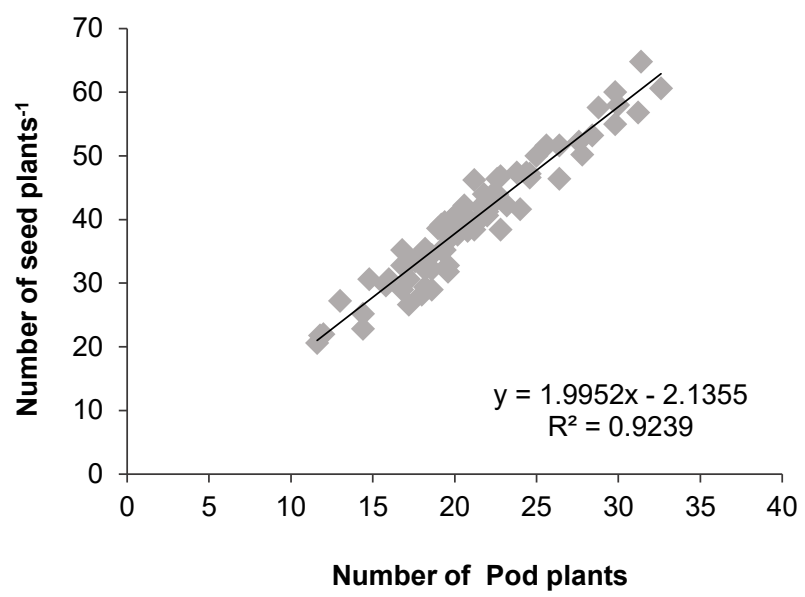

Figure 4. Relationship between number of pods plant ${ }^{-1}$ and number of seeds plant $^{-1}$ of the photosynthetic process in addition to the seed. The accumulation of photosynthate strongly influences the weight of the seed. The photosynthetic process results in pods can be maximized if the availability of water and plant nutrients is provided during photosynthesis. The pods are produced will be filled by assimilates formed in the photosynthetic process for seed formation. The number of formed seeds will depend on the number and size of the pod, so the more pods formed, the seed will also be an increase (Saeed et al. 2007; Khajudparn and Piyada 2013). A significant relationship between the number of pods formed and the number of seeds is also found in Mung bean (Vigna radiata L.).

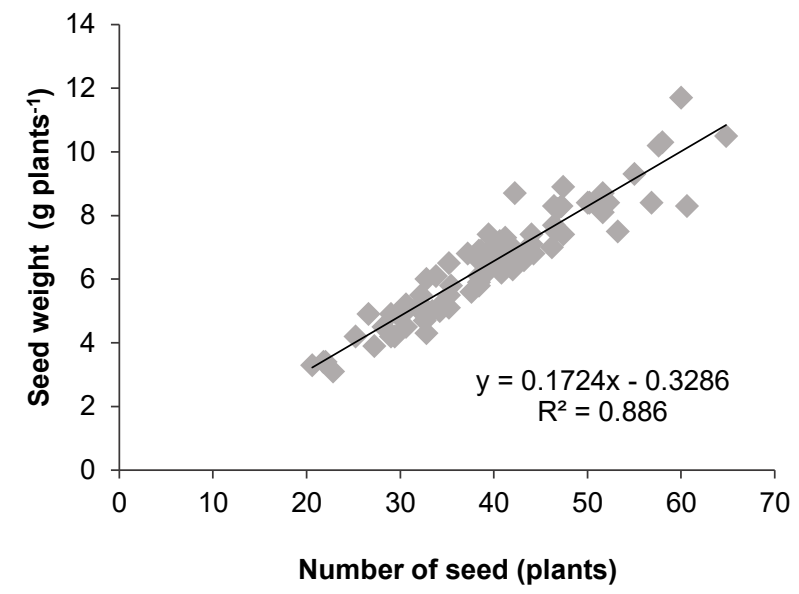

Figure 5. Relationship between number of seeds plant ${ }^{-1}$ and seed weight $\left(\right.$ g plant $\left.^{-1}\right)$

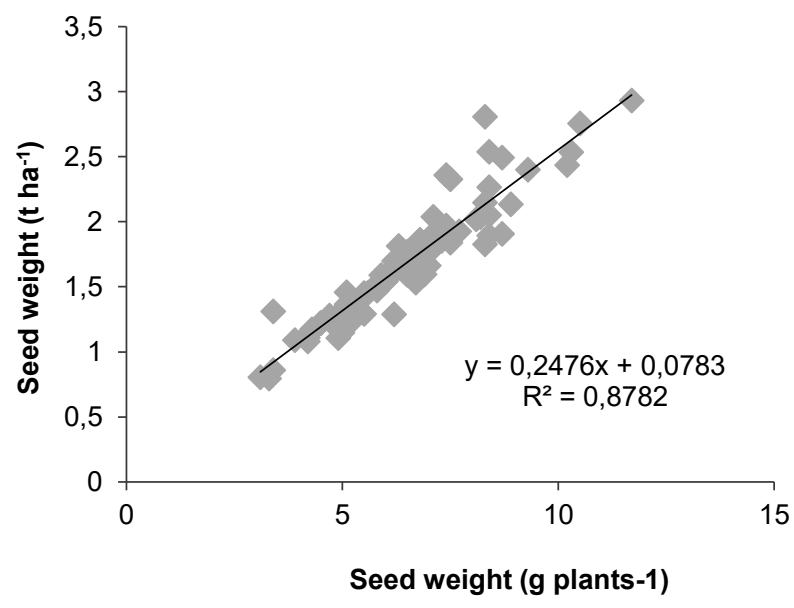

Figure 6. Relationship between Seed Weight $\left(\mathrm{g} \mathrm{plant}^{-1}\right)$ and Seed Yield $\left(\mathrm{t} \mathrm{ha}^{-1}\right)$ 


\section{CONCLUSIONS}

The application of $50 \mathrm{~kg}$ urea ha-1 and $300 \mathrm{~kg} \mathrm{SP-36}$ $\mathrm{ha}^{-1}$ can increase the leaf area and photosynthesis rate. Dosage $150 \mathrm{~kg} \mathrm{KCl} \mathrm{ha}^{-1}$ fertilizer significantly increased $\mathrm{N}, \mathrm{P}$, and $\mathrm{K}$ concentrations in the plant tissues. There is a linear relationship between Number of Pods plant ${ }^{-1}$ and Number of Seeds plant ${ }^{-1}$, Number of Seeds plant ${ }^{-1}$ and Seed Weight (g plant $\left.{ }^{-1}\right)$, Seed Weight $\left(\right.$ g plant $\left.^{-1}\right)$, and Seed Yield $\left(t \mathrm{ha}^{-1}\right)$.

\section{REFERENCES}

Ao X, Guo X, Zhu Q, Zhang H, Wang H, Ma Z, Han X, Zhao M, Xie F. 2014. Effect of Phosphorus Fertilization to P Uptake and Dry Matter Accumulation in Soybean with Different $P$ Efficiencies. J Integr Agric. 13(2):326-334. doi:10.1016/S20953119(13)60390-1.

Araújo AP, Del Pin B, Teixeira MG. 2012. Nitrogen and phosphorus in senescent leaves of field-grown common bean cultivars and their contribution to crop nutrient budget. F Crop Res. 127:35-43. doi:10.1016/j.fcr.2011.11.009.

Atkins CA, Smith PMC. 2007. Translocation in Legumes: Assimilates, Nutrients, and Signaling Molecules. Plant Physiol. 144(2):550-561. doi:10.1104/pp.107.098046.

Cuvaca I, Lambert D, Walker F, Marake M, Eash N. 2015. Economically Optimal N Fertilizer Rates for Maize Produced on Vertisol and Inceptisol Soils under No-Till Management: A Case Study in Maphutseng, Lesotho. Int J Plant Soil Sci. 8(2):1-12. doi:10.9734/IJPSS/2015/19371.

Day L. 2013. Proteins from land plants - Potential resources for human nutrition and food security. Trends Food Sci Technol. 32(1):25-42. doi:10.1016/j.tifs.2013.05.005.

Domingues TF, Meir P, Feldpausch TR, Saiz G, Veenendaal EM, Schrodt F, Bird M, Djagbletey G, Hien F, Compaore H, et al. 2010. Co-limitation of photosynthetic capacity by nitrogen and phosphorus in West Africa woodlands. Plant Cell Environ. 33(6):959-980.

3040.2010.02119.x.

Gibbs HK, Ruesch AS, Achard F, Clayton MK, Holmgren P, Ramankutty N, Foley JA. 2010. Tropical forests were the primary sources of new agricultural land in the 1980s and 1990s. In: Proceedings of the National Academy of Sciences. Vol. 107. p. 16732-16737.

Janagard MS, Raei Y, Gasemi-Golezani K, Aliasgarzad N. 2013. Soybean response to biological and chemical fertilizers. Int J Agric Crop Sci. 5(3):261266.

Jati RI, Tohari T, Suryanto P. 2017. The Optimum Dose of Nitrogen, Phosporus, and Potassium to Improve Soybean (Glycine max (L) Merr) Productivity on Kayu Putih (Melaleuca cajuputi) Stands. IImu Pertan (Agricultural Sci. 2(2):56-63. doi:10.22146/ipas.17991.
Kanai S, Moghaieb RE, El-Shemy HA, Panigrahi R, Mohapatra PK, Ito J, Nguyen NT, Saneoka H, Fujita K. 2011. Potassium deficiency affects water status and photosynthetic rate of the vegetative sink in green house tomato prior to its effects on source activity. Plant Sci. 180(2):368-374. doi:10.1016/j.plantsci.2010.10.011.

Khajudparn P, Piyada T. 2013. Relationships and variability of agronomic and physiological characters in mungbean. African J Biotechnol. 10(49):999210000. doi:10.5897/AJB11.1288.

Masuda T, Goldsmith P. 2009. World Soybean Production: Area Harvested, Yield, and Long-Term Projections. Int Food Agribus Manag Rev. 12(4):143162. doi:10.22004/ag.econ.92573.

Motaghi S, Nejad TS. 2014. The effect of different levels of humic acid and potassium fertilizer on physiological indices of growth. Int J Biosci. 5(2):99-105. doi:10.12692/ijb/5.2.99-105.

Novelli LE, Caviglia OP, Melchiori RJM. 2011. Impact of soybean cropping frequency on soil carbon storage in Mollisols and Vertisols. Geoderma. 167-168:254260. doi:10.1016/j.geoderma.2011.09.015.

Oliveira HC, Freschi L, Sodek L. 2013. Nitrogen metabolism and translocation in soybean plants subjected to root oxygen deficiency. Plant Physiol Biochem.

66:141-149. doi:10.1016/j.plaphy.2013.02.015.

Putra FP, Saparso S, Rohadi S, Ismoyojati R. 2019. Respon Tanaman Kentang (Solanum tuberosum I.) pada Berbagai Ketebalan Media Cocopeat dan Waktu Pemberian Nutrisi Sundstrom. J IIm Pertan. 15(2):57-66. doi:10.31849/jip.v15i2.1950.

Putra FP, Saparso S, Suparto SR, Faozi K. 2019. Relationship of Growth and Yield Mini Tubers of Potato Under Cocopeat Media and Frequency of Fertilizer. Bernas. 15(1):11-19.

Putra FP, Yudono P, Waluyo S. 2017. Growth and Yield of Upland Rice Under Intercropping System with Soybean in Sandy Coastal Area. IImu Pertan $\begin{array}{lll}\text { (Agricultural } & \text { Sci. }\end{array}$ doi:10.22146/ipas.25215.

Reich PB, Oleksyn J, Wright IJ. 2009. Leaf phosphorus influences the photosynthesis-nitrogen relation: a cross-biome analysis of 314 species. Oecologia. 160(2):207-212. doi:10.1007/s00442-009-1291-3.

Saeed I, Khattak GSS, Zamir R. 2007. Assosiation of seed yield and some important morphological traits in mungbean (Vigna radiata L.). Pak J Bot. 39(7):23612366.

SAS Institute Inc. 2001. Step-by-step Programming with Base SAS ${ }^{\circledR}$ Software. Cary, NC: SAS Institute Inc.

Singh SK, Reddy VR. 2016. Methods of mesophyll conductance estimation: its impact on key biochemical parameters and photosynthetic limitations in phosphorus-stressed soybean across CO 2. Physiol Plant. 157(2):234-254. doi:10.1111/ppl.12415. 
Soil Survey Staff. 2014. Keys to Soil Taxonomy. 12th ed. United States Department of Agriculture: Natural Resources Conservation Service.

Suryanto P, Putra ETS, Suwignyo B, Prianto SD, Alam T. 2017. Morpho-Physiological Characters and Soybean Productivity on Alfisol and Vertisol under Intercropping with Kayu Putih (Melaleuca cajuputi). AGRIVITA J Agric Sci. 39(2):153-159. doi:10.17503/agrivita.v39i2.759.

Tscharntke T, Clough Y, Wanger TC, Jackson L, Motzke I, Perfecto I, Vandermeer J, Whitbread A. 2012. Global food security, biodiversity conservation and the future of agricultural intensification. Biol Conserv. 151(1):53-59. doi:10.1016/j.biocon.2012.01.068.

Valentine AJ, Benedito VA, Kang Y. 2018. Legume Nitrogen Fixation and Soil Abiotic Stress: From Physiology to Genomics and Beyond. In: Annual Plant Reviews online. Chichester, UK: John Wiley \& Sons, Ltd. p. 207-248.

Zelalem A, Tekalign T, Nigussie D. 2009. Response of potato (Solanum tuberosum L.) to different rates of nitrogen and phosphorus fertilization on vertisols at Debre Berhan, in the central highlands of Ethiopia. African J Plant Sci. 3(2):16-24. 